\title{
Distribution of Methanol Carbon Between Assimilation and Oxidation Pathways in Methanol-grown Pseudomonas C
}

\author{
By A. BEN-BASSAT, I. GOLDBERG AND R. I. MATELES \\ Laboratory of Applied Microbiology, Institute of Microbiology, \\ Hebrew University-Hadassah Medical School, P.O. Box 1172, Jerusalem, Israel
}

(Received 6 March 1979)

\begin{abstract}
In Pseudomonas $\mathrm{C}$, a facultative methylotrophic bacterium, methanol is assimilated via the 2-keto-3-deoxy-6-phosphogluconate (KDPG) variant of the ribulose monophosphate (RMP) pathway of formaldehyde fixation. The oxidation of methanol to $\mathrm{CO}_{2}$ is accomplished by the direct oxidation pathway (which involves formic acid as an oxidation intermediate), via a cyclic oxidation pathway (glucose monophosphate shunt) and by other decarboxylation reactions. The distribution pattern of methanol carbon among the assimilation and the different oxidation pathways was studied by measuring the distribution between $\mathrm{CO}_{2}$ and cell constituents of ${ }^{14} \mathrm{C}$-labelled compounds after their injection into a culture growing on methanol in a chemostat. From these measurements, it was calculated that $25 \%$ of the methanol consumed by the cells was oxidized through formate to $\mathrm{CO}_{2}$, while the remainder was diverted into the hexulosephosphate synthase reaction from which $55 \%$ was assimilated through the KDPG reaction and $17 \%$ was oxidized to $\mathrm{CO}_{2}$ via a cyclic oxidation pathway and other decarboxylation reactions. The remaining $7 \%$ from the methanol carbon was re-incorporated as $\mathrm{CO}_{2}$ into cell material through carboxylation reactions.
\end{abstract}

\section{INTRODUCTION}

Some bacteria able to utilize $\mathrm{C}_{1}$ compounds (Quayle, 1961 ; Ribbons et al., 1970) assimilate them via the 2-keto-3-deoxy-6-phosphogluconate (KDPG) variant of the ribulose monophosphate (RMP) pathway of formaldehyde fixation (Strøm et al., 1974; Ben-Bassat \& Goldberg, 1977). In Pseudomonas C and in other similar bacteria [for example, Methylophilus methylotrophus (Taylor, 1977), Pseudomonas methanica and Methylococcus capsulatus (Strøm et al., 1974)] methanol is oxidized to formaldehyde which is then either oxidized to $\mathrm{CO}_{2}$ via formic acid (the direct oxidation pathway) or is incorporated into ribulose 5-phosphate to yield hexulose 6-phosphate (RMP pathway) (Fig. 1). While part of the carbon which flows via the hexulose 6-phosphate is incorporated directly into cell constituents via the KDPG aldolase reaction of the RMP pathway $(1-X$, see Fig. 1$)$ the remainder is oxidized to $\mathrm{CO}_{2}$ via a cyclic oxidation pathway (Ben-Bassat \& Goldberg, 1977) $\left(X_{1}\right.$ in Fig. 1) or via different assimilatory decarboxylation reactions $\left(X_{2}\right.$ in Fig. 1$)$ which give rise to $\mathrm{CO}_{2}$ and might operate in Pseudomonas $\mathrm{C}$ in a similar way to that found in other bacteria (Babel \& Loffhagen, 1977). Part of the $\mathrm{CO}_{2}$ released by the cells is re-incorporated into cell constituents by different carboxylation reactions as described for other RMP bacteria (Babel \& Loffhagen, 1977).

The aim of the present work was to measure the distribution of methanol carbon among the different biochemical pathways and reactions in Pseudomonas $\mathbf{C}$ grown on methanol, so as to quantify the relative importance of the various pathways. This was carried out by measuring the distribution between $\mathrm{CO}_{2}$ and cell constituents of different ${ }^{14} \mathrm{C}$-labelled compounds after their injection into a culture of Pseudomonas $\mathrm{C}$. The distribution of 


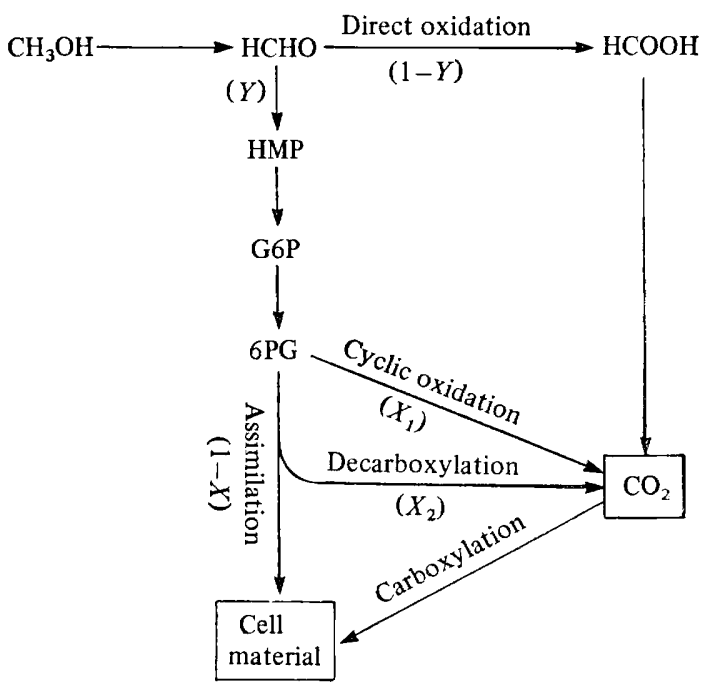

Fig. 1. Pathways of methanol metabolism in Pseudomonas C. Definitions: $X_{1}$, the flux of carbon from the cyclic oxidation pathway to $\mathrm{CO}_{2} ; X_{2}$, the flux of carbon via decarboxylation to $\mathrm{CO}_{2} ; 1-X$ (with $X=X_{1}+X_{2}$ ), the flux of carbon via the KDPG reaction to cell material; $Y$, the flux of carbon into the hexulosemonophosphate synthase reaction; $1-Y$, the flux of carbon via formic acid to $\mathrm{CO}_{2}$ (the direct oxidation pathway); HMP, hexulose monophosphate; G6P, glucose 6-phosphate; 6PG, 6-phosphogluconate.

methanol carbon was calculated from these measurements as follows: (i) the distribution of $\left[{ }^{14} \mathrm{C}\right]$ formate between $\mathrm{CO}_{2}$ and cells indicates the part of methanol carbon which is oxidized via formate to $\mathrm{CO}_{2}(1-Y$; Fig. 1$)$; (ii) the distribution of sodium $\left[{ }^{14} \mathrm{C}\right]$ bicarbonate indicates the part of methanol carbon which is assimilated into the cell by different carboxylation reactions; (iii) the distribution of $\left[{ }^{14} \mathrm{C}\right]$ glucose between $\mathrm{CO}_{2}\left(X_{1}\right)$ and cell material $(1-X)$ indicates the distribution of the part of methanol carbon which is oxidized to formaldehyde and fixed by the hexulosemonophosphate synthase reaction $(Y)$. These measurements were done during growth in substrate-limited continuous culture, which provides a system for maintaining time-invariant or steady state growth in a constant controllable environment.

\section{METHODS}

Growth of Pseudomonas C. The organism used in this study, Pseudomonas C, has been described by Chalfan \& Mateles (1972). Cells were grown in continuous culture in a New Brunswick Bioflow chemostat (model C-30) at $36{ }^{\circ} \mathrm{C}$ with an agitation rate of 700 rev. $\mathrm{min}^{-1}$ and an aeration rate of $0 \cdot 15$ vol. air (vol. growth medium) $)^{-1} \mathrm{~min}^{-1}$ in $270 \mathrm{ml}$ M-3 medium (Mateles \& Battat, 1974) at a dilution rate $(D)$ of $0.3 \mathrm{~h}^{-1}$. Methanol $\left(4 \mathrm{~g} \mathrm{l}^{-1}\right)$, glucose $\left(0 \cdot 1 \mathrm{~g} \mathrm{l}^{-1}\right)$ or formic acid $\left(3 \mathrm{~g} \mathrm{l}^{-1}\right)$ were added to the medium reservoir as described in the text. The culture was maintained at $\mathrm{pH} 6 \cdot 9 \pm 0 \cdot 1$ by automatic addition of aqueous $\mathrm{NaOH}$. Culture density was measured at $650 \mathrm{~nm}$ with a Gilford spectrophotometer (model 240). The steady state concentrations of cells and substrates were measured after a period of at least 10 residence times, i.e. about $30 \mathrm{~h}$, had elapsed after a change in growth conditions.

Distribution of label. After a steady state in growth was achieved, 1 to $2 \mu \mathrm{Ci}$ of the appropriate ${ }^{14} \mathrm{C}$ labelled compound was injected into the culture medium in the growth vessel. The $\mathrm{CO}_{2}$ in the air leaving the growth vessel (free $\mathrm{CO}_{2}$ ) was absorbed in $4 \mathrm{M}-\mathrm{NaOH}$. The culture suspension in the effluent stream of the growth vessel was collected in an ice-cooled container and cells were separated by centrifugation $(10000 \mathrm{~g}$, $4{ }^{\circ} \mathrm{C}, 15 \mathrm{~min}$ ). As some lysis of cells occurred during the collection of the suspension, the cell-free supernatant fluid was brought to a concentration of $10 \%(\mathrm{w} / \mathrm{v})$ trichloroacetic acid (TCA) and re-centrifuged. The sediment obtained (which contained about $5 \%$ of the radioactivity found in the precipitated cells) was subsequently treated together with the cells, and these two fractions together are reported as 'cells' or 'cell constituents'.

A sample of the effluent cell suspension was adjusted to $\mathrm{pH} 2.5$ with $11 \mathrm{M}-\mathrm{HCl}$ and a stream of $\mathrm{N}_{2}$ was 
passed through it for $12 \mathrm{~h}$ to remove the $\mathrm{CO}_{2}$ present in the broth either as bicarbonate or dissolved $\mathrm{CO}_{2}$. The $\mathrm{CO}_{2}$ was absorbed from the $\mathrm{N}_{2}$ stream in $4 \mathrm{M}-\mathrm{NaOH}$. Total $\mathrm{CO}_{2}$ included the free $\mathrm{CO}_{2}$ as well as that stripped by $\mathrm{N}_{2}$ after acidification of the cell suspension.

For liquid scintillation counting, the cells and the TCA precipitate were dissolved in a solution of $0 \cdot 1 \mathrm{M}-$ $\mathrm{NaOH}$ containing $0 \cdot 2 \mathrm{M}$-sodium dodecyl sulphate by heating for $2 \mathrm{~h}$ at $90^{\circ} \mathrm{C}$. Counting was done in Bray's solution (Bray, 1960), using [methyl $\left.{ }^{14} \mathrm{C}\right]$ toluene as an internal standard. Counting efficiency was about $80 \%$. The $\mathrm{CO}_{2}$ was counted by precipitating with $\mathrm{BaCl}_{2}$, filtering on Whatman $\mathrm{GF} / \mathrm{C}$ filters and washing the precipitate on the filters with $0.05 \mathrm{M}-\mathrm{BaCl}_{2}$ followed by ethanol. Filters were dried and counted in Bray's solution. For standardization, a known quantity of sodium $\left[{ }^{14} \mathrm{C}\right]$ bicarbonate was added to a trap containing $4 \mathrm{M}-\mathrm{NaOH}$ and treated in parallel. Counting efficiency was about $80 \%$.

Radioactivity in the culture broth was determined by counting a sample of the supernatant fluid obtained after precipitating the cells from the cell suspension and subtracting the counts found in a parallel sample treated with TCA and stripped of dissolved $\mathrm{CO}_{2}$ and bicarbonate by $\mathrm{N}_{2}$.

For evaluation of the distribution of label, cells and broth were collected from the fermenter for $24 \mathrm{~h}$ following the injection of the labelled compound, and $\mathrm{CO}_{2}$ was collected for $12 \mathrm{~h}$. These periods were sufficient to ensure the collection of more than $98 \%$ of added ${ }^{14} \mathrm{C}$.

Reduction of formate to formaldehyde. To determine the amount of formaldehyde excreted into the medium after the addition of sodium $\left[{ }^{14} \mathrm{C}\right]$ formate, cells were grown in $\mathrm{M}-3$ medium with methanol $\left(4 \mathrm{~g} \mathrm{I}^{-1}\right)$ and harvested during the exponential phase of growth. The cells were washed and resuspended at $1.4 \mathrm{mg}$ dry wt $\mathrm{ml}^{-1}$ in $20 \mathrm{ml}$ fresh medium in $250 \mathrm{ml}$ Erlenmeyer flasks. The medium contained $25 \mathrm{~mm}$-methanol, $2.5 \mathrm{~mm}-$ sodium formate, $5 \mathrm{~mm}$-sodium sulphite and $0 \cdot 1$ to $0 \cdot 3 \mu \mathrm{Ci}$ sodium $\left[{ }^{14} \mathrm{C}\right]$ formate. Following incubation for $1 \mathrm{~h}$ at $35^{\circ} \mathrm{C}$ with agitation, the cell suspensions were centrifuged and the cell-free supernatant solutions were analysed for formaldehyde using the procedure described by Taylor \& Weisstuach (1965). The dimedone-formaldehyde complexes were filtered on Whatman GF/B filters and the filters were counted in Bray's solution. Under these conditions the production of $\left[{ }^{14} \mathrm{C}\right]$ formaldehyde from $\left[{ }^{14} \mathrm{C}\right]$ formate could not be detected, although $40 \%$ of $\left[{ }^{14} \mathrm{C}\right]$ formaldehyde added to the culture as a control was reproducibly recovered. As a further control, the production of formaldehyde was measured after addition of $\left[{ }^{14} \mathrm{C}\right] \mathrm{methanol}$, instead of sodium $\left[{ }^{14} \mathrm{C}\right]$ formate, to the cell suspension. Approximately $8 \%$ of the methanol could be trapped as formaldehyde under these assay conditions.

Enzyme assays. Preparation of cell extracts and assays of phenazine methosulphate-linked methanol dehydrogenase [EC 1.1.99.8], formaldehyde dehydrogenase [fcrmaldehyde: $\mathrm{NAD}^{+}$oxidoreductase; EC 1.2.1.1], formate dehydrogenase [formate: $\mathrm{NAD}^{+}$oxidoreductase; EC 1.2.1.2] and 3-hexulosephosphate synthase [D-arabino-3-hexulose-6-phosphate formaldehyde-lyase] were carried out as previously described by Ben-Bassat \& Goldberg (1977). 6-Phosphofructokinase [ATP:D-fructose-6-phosphate 1phosphotransferase; EC 2.7.1.11] was determined according to Ling et al. (1966). Glucose-6-phosphate dehydrogenase [D-glucose-6-phosphate: $\mathrm{NADP}^{+}$1-oxidoreductase; EC 1.1.1.49] assay mixtures contained (in a total volume of $1.0 \mathrm{ml}$ ) $100 \mu \mathrm{mol}$ Tris/ $\mathrm{HCl}$ buffer $(\mathrm{pH} 8.4$ ), $5 \mu \mathrm{mol}$ D-glucose 6 -phosphate, $0.5 \mu \mathrm{mol}$ $\mathrm{NAD}^{+}$and various amounts of extract. The mixtures for assay of 6-phosphogluconate dehydrogenase [6-phospho-D-gluconate:NADP ${ }^{+}$2-oxidoreductase (decarboxylating); EC 1.1.1.44] contained (in a total volume of $1.0 \mathrm{ml}$ ) $100 \mu \mathrm{mol}$ glycylglycine buffer $(\mathrm{pH} 8.4) ; 1 \mu \mathrm{mol}$ 6-phosphogluconate; $0.2 \mu \mathrm{mol} \mathrm{NADP}^{+}$ and various amounts of extract. Assays of the different enzymes were performed at $30^{\circ} \mathrm{C}$.

Chemical determinations. Protein was determined, after precipitation with $10 \%(\mathrm{w} / \mathrm{v})$ TCA, by Lowry's method using bovine serum albumin as a standard. Methanol, formic acid and dry weight of cells were determined as described by Goldberg et al. (1976). Glucose was determined using glucose oxidase (Boehringer).

Chemicals. Sodium $\left[{ }^{14} \mathrm{C}\right]$ formate $\left(59 \mathrm{Ci} \mathrm{mol}^{-1}\right)$, D- $\left[\mathrm{U}-{ }^{14} \mathrm{C}\right]$ glucose $\left(230 \mathrm{Ci} \mathrm{mol}^{-1}\right),\left[{ }^{14} \mathrm{C}\right] \mathrm{methanol}(58 \mathrm{Ci}$ $\left.\mathrm{mol}^{-1}\right)$, [methyl- $\left.{ }^{14} \mathrm{C}\right]$ toluene $\left(1 \cdot 2 \times 10^{6} \mathrm{~d}\right.$.p.m. $\left.\mathrm{g}^{-1}\right)$ and sodium $\left[{ }^{14} \mathrm{C}\right]$ bicarbonate $\left(0 \cdot 1 \mathrm{Ci} \mathrm{mol}{ }^{-1}\right)$ were obtained from The Radiochemical Centre, Amersham. All chemicals used were of analytical grade.

\section{RESULTS}

Distribution of label between $\mathrm{CO}_{2}$ and cell material during growth on methanol

A radioactive tracer experiment was performed with a steady state culture of Pseudomonas C grown on methanol $\left(4 \mathrm{~g}^{-1}\right)$ at $D=0 \cdot 3 \mathrm{~h}^{-1}$ to assess the distribution of carbon from methanol between $\mathrm{CO}_{2}$ and cell material. A pulse of $\left[{ }^{14} \mathrm{C}\right]$ methanol was introduced into the culture medium in the fermenter and samples of the outlet medium and air stream were taken over a period of $24 \mathrm{~h}$. Essentially all of the ${ }^{14} \mathrm{C}$ in $\mathrm{CO}_{2}$ had been released during the first $12 \mathrm{~h}$, while almost all of the ${ }^{14} \mathrm{C}$ in the cells was recovered after $24 \mathrm{~h}$ (Fig. $2 a$ ). 

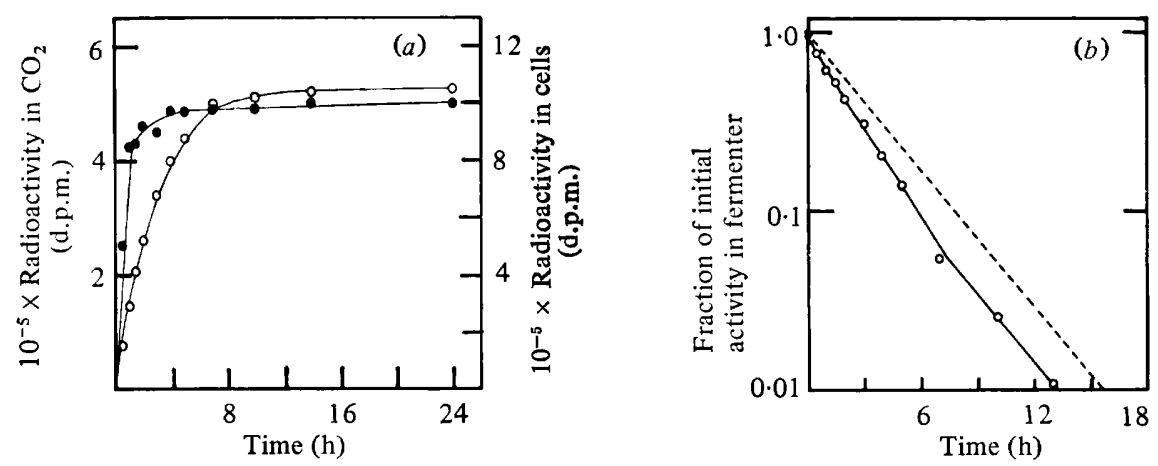

Fig. 2. Kinetics of recovery of ${ }^{14} \mathrm{C}$ from a continuous culture. Pseudomonas $\mathrm{C}$ was grown in $\mathrm{M}-3$ medium with methanol $\left(4 \mathrm{~g} \mathrm{I}^{-1}\right)$ at a dilution rate of $0.3 \mathrm{~h}^{-1}$. At zero time, $\left.{ }^{14} \mathrm{C}\right] \mathrm{methanol}\left(18 \times 10^{5}\right.$ d.p.m.) was injected into the culture medium in the fermenter. (a) Recovery of ${ }^{14} \mathrm{C}$ in the cells (O) and $\mathrm{CO}_{2}(\mathrm{O})$ following injection of $\left[{ }^{14} \mathrm{C}\right]$ methanol. (b) Dilution of ${ }^{14} \mathrm{C}$ from the growth vessel following injection of $\left[{ }^{14} \mathrm{C}\right]$ methanol. The theoretical curve (---) was calculated from the liquid phase dilution rate. The experimental curve (-) deviates from the theoretical curve due to the fact that ${ }^{14} \mathrm{C}$ in $\mathrm{CO}_{2}$ formed from methanol (see text) is more rapidly diluted than the ${ }^{14} \mathrm{C}$ in the cells and the methanol because of gassing.

Table 1. Distribution of radioactivity after addition of ${ }^{14} \mathrm{C}$-labelled compounds
to steady state continuous cultures of Pseudomonas $\mathrm{C}$ grown on methanol

Cultures were grown on methanol $\left(4 \mathrm{~g}^{-1}\right)$ at $D=0 \cdot 3 \mathrm{~h}^{-1}$.

\begin{tabular}{|c|c|c|c|c|}
\hline \multirow[b]{2}{*}{ Compound added } & \multicolumn{3}{|c|}{$10^{-3} \times$ Radioactivity (d.p.m.) } & \multirow{2}{*}{$\begin{array}{c}\begin{array}{c}\text { Ratio of } \\
\text { radioactivities } \\
\text { Cells }\end{array} \\
\mathrm{CO}_{2}+\text { Cells }\end{array}$} \\
\hline & Cells & $\mathrm{CO}_{2}$ & $\begin{array}{c}\text { Culture } \\
\text { broth }\end{array}$ & \\
\hline$\left[{ }^{14} \mathrm{C}\right]$ Methanol & 1006 & 610 & $54 \cdot 6$ & 0.62 \\
\hline Sodium $\left[{ }^{14} \mathrm{C}\right]$ formate & 411 & 2242 & 225 & $0 \cdot 155$ \\
\hline Sodium $\left[{ }^{14} \mathrm{C}\right]$ formate* & 358 & 3670 & 203 & 0.083 \\
\hline $\mathrm{D}-\left[\mathrm{U}-{ }^{14} \mathrm{C}\right]$ Glucose $\dagger$ & 1994 & 563 & 1614 & 0.78 \\
\hline Sodium $\left[{ }^{14} \mathrm{C}\right]$ bicarbonate & 303 & 1652 & ND & $0 \cdot 15$ \\
\hline
\end{tabular}

ND, Not determined.

* Inlet air stream was enriched to approximately $5 \% \mathrm{CO}_{2}$ at an aeration rate of $0 \cdot 3 \mathrm{vol}$. vol. ${ }^{-1} \mathrm{~min}^{-1}$.

$\dagger$ In addition to methanol, the medium contained glucose $\left(0 \cdot 1 \mathrm{~g}^{-1}\right)$.

A comparison between the wash-out curve from the chemostat and one calculated on the assumption that all the ${ }^{14} \mathrm{C}$ remains in the cells or liquid phase (Fig. $2 b$ ) showed that the dilution rate of the ${ }^{14} \mathrm{C}$ from the growth vessel during the first hours after label injection of $\left[{ }^{4} \mathrm{C}\right]$ methanol was greater than the calculated rate. This difference was due to oxidation of some of the $\left[{ }^{14} \mathrm{C}\right]$ methanol to ${ }^{14} \mathrm{CO}_{2}$, which was removed from the fermenter by aeration faster than the liquid phase components. However, by $6 \mathrm{~h}$ after the addition most of the $\left[{ }^{14} \mathrm{C}\right]$ methanol that could be oxidized had been removed from the growth vessel and the remainder had been fixed in cell material (Fig. $2 a$ ), so the dilution rate of ${ }^{14} \mathrm{C}$ became identical to that of the liquid phase (Fig. 2b).

The concentrations of methanol, formic acid, $\mathrm{CO}_{2}$ and glucose in the culture medium were determined. Under steady state conditions the concentration of methanol in the culture medium in the growth vessel was about $40 \mathrm{mg}^{-1}$. The concentration of formic acid, when methanol was the sole carbon source, was $12 \mathrm{mg} \mathrm{l}^{-1}$ and the concentration of $\mathrm{CO}_{2}$ in the exit gas stream was estimated by calculation to be about $3 \%(\mathrm{v} / \mathrm{v})$. The concentration of glucose in the culture medium when methanol $\left(4 \mathrm{~g} \mathrm{l}^{-1}\right)$ and glucose $\left(0 \cdot 1 \mathrm{~g} \mathrm{l}^{-1}\right)$ were used as carbon sources was $0.05 \mathrm{~g} \mathrm{1}^{-1}$.

Table 1 shows the results obtained when different ${ }^{14} \mathrm{C}$-labelled compounds were injected 


\section{Table 2. Distribution of methanol carbon between assimilation and oxidation pathways in Pseudomonas $\mathrm{C}$ grown on methanol or methanol plus formate}

Cells were grown in continuous culture with methanol $\left(4 \mathrm{~g}^{-1}\right)$ or methanol $\left(4 \mathrm{~g} \mathrm{l}^{-1}\right)$ plus formic acid $\left(3 \mathrm{~g}^{-1}\right)$ at $D=0.3 \mathrm{~h}^{-1}$. For definitions of $X, 1-X, Y$ and $1-Y$, see Fig. 1 . The results show the mol fraction of methanol carbon participating in the various pathways from $1 \mathrm{~mol}$ methanol utilized.

\begin{tabular}{|c|c|c|c|}
\hline \multirow[b]{2}{*}{ Metabolic pathway } & \multicolumn{3}{|c|}{ Mol fraction of methanol carbon } \\
\hline & $\ldots$ & Methanol & $\begin{array}{l}\text { Methanol+ } \\
\text { formate }\end{array}$ \\
\hline Direct oxidation: $\mathrm{CO}_{2}$ release $(1-Y)$ & & $0 \cdot 25$ & $0 \cdot 16$ \\
\hline Hexulosemonophosphate synthase reaction $(Y)$ & & 0.75 & $0 \cdot 84$ \\
\hline Assimilation into cell constituents $(1-X)$ & & 0.55 & 0.66 \\
\hline $\begin{array}{l}\text { Cyclic oxidation and decarboxylation reactions: } \\
\mathrm{CO}_{2} \text { release }(X)\end{array}$ & & $0 \cdot 20$ & $0 \cdot 18$ \\
\hline $\begin{array}{l}\text { Re-incorporation of } \mathrm{CO}_{2} \text { into cell constituents: } \\
\text { carboxylation reactions }\end{array}$ & & 0.07 & 0.05 \\
\hline Total $\mathrm{CO}_{2}$ release by cells & & $0 \cdot 38$ & $0 \cdot 29$ \\
\hline
\end{tabular}

into the growth vessel of a steady state culture of $\boldsymbol{P}_{\text {seudomonas }} \mathrm{C}$ grown on methanol at $D=0.3 \mathrm{~h}^{-1}$. In calculating the partitioning of label between cells and $\mathrm{CO}_{2}$, the radioactivity present in the culture broth was ignored.

\section{Calculation of carbon fluxes during growth on methanol}

The fluxes of methanol "carbon in Pseudomonas $\mathrm{C}$ were calculated from the results presented in Table 1 on the basis of 1 mol methanol consumed by the cells and making four assumptions: (i) the addition of different labelled compounds to the culture medium did not change the concentration of the compounds in the culture medium in the growth vessel, i.e. they served only as tracers: (ii) glucose, because it is assimilated in Pseudomonas $\mathrm{C}$ only via the KDPG pathway and is oxidized to $\mathrm{CO}_{2}$ via glucose-6-phosphate dehydrogenase and 6-phosphogluconate dehydrogenase and decarboxylation reactions (see Fig. 1), served as a tracer for these pathways; (iii) formic acid was oxidized to $\mathrm{CO}_{2}$ and was neither reduced to formaldehyde nor incorporated directly into cells; (iv) the amount of ${ }^{14} \mathrm{CO}_{2}$ incorporated into cells was an indication of the net incorporation of $\mathrm{CO}_{2}$ into this fraction. Justifications for these assumptions are provided in the Discussion.

The first step in calculating the fluxes of methanol carbon among the different pathways is the determination of the flux of methanol carbon to $\mathrm{CO}_{2}$ from the operation of the cyclic oxidation pathway and decarboxylations in the assimilatory pathway. If we let $X_{1}$ and $X_{2}$ represent the fluxes to $\mathrm{CO}_{2}$ from the cyclic pathway and decarboxylation reactions, respectively (see Fig. 1), then we can define $X=X_{1}+X_{2}$ and $1-X$ as the flux of carbon via the assimilation pathway into cell material. Table 1 shows that $15 \%$ of the ${ }^{14} \mathrm{C}$ from $\left[{ }^{14} \mathrm{C}\right]-$ bicarbonate was incorporated in cell material as a result of carboxylation reactions fed from the pool of $\mathrm{CO}_{2}$ or $\left[{ }^{14} \mathrm{C}\right]$ bicarbonate. For the distribution of ${ }^{14} \mathrm{C}$ arising from the use of $\left[{ }^{14} \mathrm{C}\right]$ glucose, Table 1 indicates that $78 \%$ of the ${ }^{14} \mathrm{C}$ was in the cells (including re-incorporation of $\mathrm{CO}_{2}$ into cells via carboxylation reactions) and hence $22 \%$ appeared in $\mathrm{CO}_{2}$. Using assumption (ii) (above), all the glucose carbon flows through either the cyclic oxidation pathway or the assimilation pathway, and hence $(1-X)+0 \cdot 15 X=0 \cdot 78$. Thus $X=0 \cdot 26$, representing the flux of carbon to $\mathrm{CO}_{2}$ from the cyclic oxidation pathway and decarboxylation reactions, and the flux of carbon into the cell is $1-0 \cdot 26=0 \cdot 74$. These same relative fluxes also apply to the carbon entering the RMP pathway via reaction between formaldehyde and ribulose 5-phosphate. It should be noted that we cannot quantify separately the $\mathrm{CO}_{2}$ produced directly from the cyclic oxidation and that arising from 


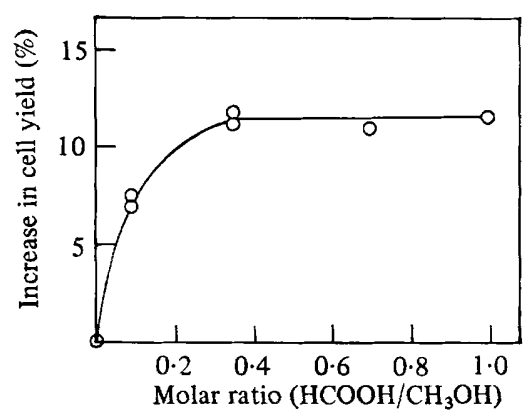

Fig. 3. Effect of formic acid on the cell yield of methanol-grown Pseudomonas C. Cells were grown in a continuous culture with methanol $\left(4 \mathrm{~g} \mathrm{l}^{-1}\right)$ at a dilution rate of $0 \cdot 3 \mathrm{~h}^{-1}$. Different amounts of formic acid were added to the medium reservoir and the increase in cell yield was estimated after a steady state in growth was achieved. The increase in cell yield is given as a percentage of the yield obtained from growth on methanol alone.

decarboxylation reactions in the assimilation pathway. These two sources are treated together.

Next, one can calculate the flux of carbon into the RMP pathway as compared to direct oxidation via formate. Let $Y$ equal the flux of carbon from formaldehyde into the RMP pathway, and $(1-Y)$ equal the flux into formic acid. From Table 1, the fraction of methanol carbon, all of which is converted into formaldehyde carbon, that is incorporated into cell material is $62 \%$. Thus, the conversion into cell material can be calculated as $0.62=[0.26 Y+$ $(1-Y)] 0 \cdot 15+0 \cdot 74 Y$, in which the first term represents re-incorporation of $\mathrm{CO}_{2}$ into cells and the second term represents the direct incorporation of carbon into cell material. Thus $Y=0.75$, and the flux of carbon into $\mathrm{CO}_{2}$ via the cyclic oxidation 'pathway and decarboxylation reactions is $0.26 \times 0.75=0.20\left(X_{1}+X_{2}\right.$ in Fig. 1$)$. The net flux into cell material via the KDPG aldolase reaction is $0.74 \times 0.75=0.55(1-X$ in Fig. 1$)$, and the net flux of carbon via formate to $\mathrm{CO}_{2}$ is $1.0-0.75=0.25\left(1-Y\right.$ in Fig. 1). Re-incorporation of $\mathrm{CO}_{2}$ into cell material is $0 \cdot 15 \times(0 \cdot 25+0 \cdot 20)=0 \cdot 07$, via carboxylation reactions (see Fig. 1). Table 2 summarizes these results for Pseudomonas $\mathrm{C}$ grown on methanol.

\section{Growth of Pseudomonas $\mathrm{C}$ on methanol plus formate}

In the previous experiments, methanol was used as the sole carbon source and therefore the growth of Pseudomonas $\mathrm{C}$ was limited both for carbon and energy. It was of interest to study the flow of methanol carbon via the different biochemical pathways under conditions in which the growth of this bacterium was limited for carbon but not for energy. These conditions were achieved when formic acid was added to the growth medium in addition to methanol and the two compounds together were growth-limiting.

There was an increase in yield, calculated on the basis of the methanol used, of approximately $12 \%$ when $0.4 \mathrm{~mol}$ formic acid (mol methanol) ${ }^{-1}$ was added (Fig. 3); above this concentration of formic acid no further increase in yield was obtained. Over the range of formic acid concentrations plotted in Fig. 3, the concentration of methanol in the culture broth in the growth vessel was stable at $40 \mathrm{mg} \mathrm{I}^{-1}$ and the concentration of formic acid in the broth ranged from $50 \mathrm{mg} \mathrm{l}^{-1}$, at a molar ratio of $0 \cdot 1$, to $97 \mathrm{mg}^{-1}$, at a molar ratio of 0.7 . Thus, there was virtually complete utilization of both substrates. At a molar ratio of 1.4 between formic acid and methanol, a steady state could not be obtained, as the formic acid concentration became high enough (about $420 \mathrm{mg}^{1-1}$ in the culture broth) to inhibit growth, and wash-out occurred. 
Table 3. Distribution of radioactivity after addition of ${ }^{14} C$-labelled compounds to steady state continuous cultures of Pseudomonas $\mathrm{C}$ grown on methanol plus formate

Cultures were grown on methanol $\left(4 \mathrm{~g} \mathrm{l}^{-1}\right)$ plus formic acid $\left(3 \mathrm{~g}^{-1}\right)$ at $D=0.3 \mathrm{~h}^{-1}$.

\begin{tabular}{|c|c|c|c|c|}
\hline \multirow[b]{3}{*}{ Compound added } & \multicolumn{3}{|c|}{$10^{-3} \times$ Radioactivity (d.p.m.) } & \multirow{2}{*}{$\begin{array}{c}\text { Ratio of } \\
\text { radioactivities } \\
\text { Cells } \\
\end{array}$} \\
\hline & & & Culture & \\
\hline & Cells & $\mathrm{CO}_{2}$ & broth & $\overline{\mathrm{CO}_{2}+\text { Cells }}$ \\
\hline$\left[{ }^{14} \mathrm{C}\right]$ Methanol & 770 & 308 & 190 & 0.71 \\
\hline Sodium $\left[{ }^{14} \mathrm{C}\right]$ formate & 368 & 2085 & 27 & $0 \cdot 15$ \\
\hline $\mathrm{D}-\left[\mathrm{U}-{ }^{14} \mathrm{C}\right] \mathrm{Glucose}{ }^{*}$ & 1375 & 319 & 896 & $0 \cdot 81$ \\
\hline Sodium $\left[{ }^{14} \mathrm{C}\right]$ bicarbonate & 303 & 1569 & 52 & $0 \cdot 16$ \\
\hline
\end{tabular}

* In addition to methanol and formate, the medium contained glucose $\left(0 \cdot 1 \mathrm{~g} \mathrm{l}^{-1}\right)$.

Table 4. Distribution of methanol carbon between assimilation and oxidation pathways in Pseudomonas $\mathrm{C}$ grown on methanol or methanol plus formate

Cells were grown in continuous culture with methanol $\left(4 \mathrm{~g}^{-1}\right)$ or methanol $\left(4 \mathrm{~g} \mathrm{l}^{-1}\right)$ plus formic acid $\left(3 \mathrm{~g}^{-1}\right)$ at $D=0 \cdot 3 \mathrm{~h}^{-1}$. For definitions of $X, 1-X, Y$ and $1-Y$, see Fig. 1. Calculations of the fluxes of methanol carbon were made with the assumption that there was no net incorporation of $\mathrm{CO}_{2}$ into cell constituents. The results show the mol fraction of methanol carbon participating in the various pathways from $1 \mathrm{~mol}$ methanol utilized.

\begin{tabular}{lccc}
\multicolumn{1}{c}{$\begin{array}{r}\text { Growth } \\
\text { medium }\end{array}$} & $\ldots$ & Methanol & $\begin{array}{c}\text { Methanol+ } \\
\text { formate }\end{array}$ \\
$\begin{array}{l}\text { Direct oxidation: } \mathrm{CO}_{2} \text { release }(1-Y) \\
\text { Hexulosemonophosphate synthase reaction }(Y)\end{array}$ & $0 \cdot 21$ & $0 \cdot 12$ \\
$\begin{array}{l}\text { Assimilation into cell constituents }(1-X) \\
\text { Cyclic oxidation and decarboxylation reactions: }\end{array}$ & $0 \cdot 79$ & $0 \cdot 88$ \\
$\mathrm{CO}_{2}$ release $(X)$ & $0 \cdot 62$ & $0 \cdot 71$ \\
$\mathrm{Re}$-incorporation of $\mathrm{CO}_{2}$ into cell constituents: & 0 & $0 \cdot 17$ \\
carboxylation reactions & & 0 \\
Total $\mathrm{CO}_{2}$ release by cells & $0 \cdot 38$ & $0 \cdot 29$
\end{tabular}

\section{Distribution of label during growth on methanol plus formate}

Table 3 presents results relating to the distribution of label obtained when ${ }^{14} \mathrm{C}$-labelled compounds were injected into steady state continuous cultures of Pseudomonas $\mathrm{C}$ grown on methanol plus formic acid. The molar ratio of formic acid to methanol was 0.52 , which was just above the ratio at which no further increase in the yield was obtained (Fig. 3). The fraction of methanol carbon incorporated into cell material increased from 0.62 to 0.71 , i.e. by $15 \%$, as a result of the presence of formic acid in an amount adequate to saturate the cell's ability to derive useful energy from the oxidation of formic acid (compare Tables 1 and 3).

Table 2 shows the fluxes of methanol carbon calculated from the results given in Table 3 , using the same assumptions and procedure as were used for the calculations for growth on methanol alone (see above). The mol fractions given in Table 2 relate to methanol and to intermediary compounds arising from the metabolism of methanol only, i.e. exogenous formic acid was not included in the calculations.

\section{Calculation of methanol carbon fluxes when no net incorporation of $\mathrm{CO}_{2}$ into cell material occurs}

Table 4 presents results on the fluxes of methanol carbon calculated on the basis that the incorporation of ${ }^{14} \mathrm{CO}_{2}$ into cell material was due to $\mathrm{CO}_{2}$ exchange reactions and not 


\section{Table 5. Specific activities of enzymes in Pseudomonas $\mathbf{C}$ grown on methanol or methanol plus formate}

Cells were grown in continuous culture with methanol $\left(4 \mathrm{~g}^{-1}\right)$ or methanol $\left(4 \mathrm{~g} \mathrm{l}^{-1}\right)$ plus formic acid $\left(3 \mathrm{~g} \mathrm{l}^{-1}\right)$ at $D=0 \cdot 3 \mathrm{~h}^{-1}$. Specific activities are expressed as $\mu$ mol substrate utilized or product formed $\min ^{-1}$ (mg protein)-1. In vitro enzyme activities were determined in extracts of cells as described in Methods. In vivo enzyme activities were calculated as described in Results.

\begin{tabular}{|c|c|c|c|c|}
\hline \multirow[b]{3}{*}{ Enzyme } & \multicolumn{4}{|c|}{ Specific activities of enzymes } \\
\hline & \multicolumn{2}{|c|}{ Growth on methanol } & \multicolumn{2}{|c|}{ Growth on methanol + formate } \\
\hline & In vitro & In vivo & In vitro & In vivo \\
\hline Methanol dehydrogenase & $0 \cdot 10$ & $0 \cdot 50$ & 0.07 & 0.45 \\
\hline Formaldehyde dehydrogenase & 0.01 & $0 \cdot 13$ & 0.01 & 0.07 \\
\hline Formate dehydrogenase & 0.08 & $0 \cdot 14$ & 0.06 & $0 \cdot 31$ \\
\hline 3-Hexulosephosphate synthase & $2 \cdot 00$ & $0 \cdot 38$ & ND & $0 \cdot 38$ \\
\hline Glucose-6-phosphate dehydrogenase* & $0 \cdot 91$ & $\mathrm{NC}$ & 1.05 & $\mathrm{NC}$ \\
\hline 6-Phosphogluconate dehydrogenase* & $0 \cdot 12$ & $\mathrm{NC}$ & $0 \cdot 17$ & NC \\
\hline
\end{tabular}

NC, Not calculated; ND, not determined.

* Enzyme activity was measured with $\mathrm{NADP}^{+}$as the coenzyme.

as a result of net incorporation of $\mathrm{CO}_{2}$. As can be seen from a comparison with Table 2, omitting the effect of $\mathrm{CO}_{2}$ incorporation from the calculation caused an increase in the part of methanol carbon assimilated via the KDPG aldolase reaction and a decrease in the part of methanol carbon oxidized to $\mathrm{CO}_{2}$ both via formate and via the cyclic oxidation pathway.

\section{In vivo and in vitro activities of different enzymes}

From the results presented in Table 2, it is possible to calculate the activities of various enzymes involved in the metabolism of methanol (in vivo), and these can be compared with the enzyme activities measured in cell-free extracts (in vitro). The rate of methanol uptake by the cells was $0.3 \times 0 \cdot 27 \times 4=0.324 \mathrm{~g} \mathrm{~h}^{-1}$, or $169 \mu \mathrm{mol} \mathrm{min}{ }^{-1}$. The cell concentration in the growth vessel was approximately $2 \mathrm{~g} \mathrm{l}^{-1}$ and the protein content was about $62 \%$ (Chalfan \& Mateles, 1972), so that the specific rate of methanol utilization was $169 /(2000 \times 0.27 \times 0.62)=0.505 \mu \mathrm{mol}(\mathrm{mg} \text { protein })^{-1} \mathrm{~min}^{-1}$. The in vivo activities of the various enzymes can be calculated by multiplying this figure by the mol fractional flux of the particular fraction, as presented in Fig. 1 and Table 2 for those cases in which the production of $1 \mathrm{~mol}$ product results from the incorporation of $1 \mathrm{~mol}$ methanol or methanol equivalent. This is the case for methanol, formaldehyde and formate dehydrogenases and for hexulosephosphate synthase.

The actual in vivo activities calculated for the various enzymes are presented in Table 5 for growth on methanol and for growth on methanol plus formic acid. In the latter case, the values reflect the $12 \%$ increase in dry weight owing to the utilization of formic acid; and the increase in the activity of formate"dehydrogenase, during growth on methanol plus formic acid, reflects the oxidation of the exogenous formic acid $\left(88 \mu \mathrm{mol} \mathrm{min}^{-1}\right)$ to $\mathrm{CO}_{2}$. Also presented in Table 5 are the activities of the various enzymes as measured in in vitro assays. A large increase in the in vivo activity of formate dehydrogenase was found when formic acid-supplemented medium was used, whereas the in vivo formaldehyde dehydrogenase activity decreased. The in vitro activities of these enzymes under the two sets of growth conditions showed no significant changes. 


\section{DISCUSSION}

The present work considers the flux of carbon from methanol among different biochemical pathways leading to the production of cell biomass and $\mathrm{CO}_{2}$ in Pseudomonas $\mathrm{C}$. As noted in Results, four assumptions were made for calculating the distribution of methanol carbon between the assimilation and the different dissimilation pathways.

(i) ${ }^{14} \mathrm{C}$-Labelled methanol, formic acid, glucose and sodium bicarbonate which were injected into the culture medium in the growth vessel can be used as tracers of methanol metabolism in Pseudomonas C. This assumption is justified since the concentration of each of these metabolites was constant in the culture broth during the steady state growth, and the labelled compound added did not significantly change the concentration in the broth or in the cells.

(ii) $\left[\mathrm{U}-{ }^{14} \mathrm{C}\right] \mathrm{Glucose}$ can be used as a tracer for that part of methanol carbon participating in the KDPG aldolase reaction, the cyclic oxidation pathway and other assimilatory decarboxylation reactions. This assumption is supported by several observations: $(a)$ activities of phosphofructokinase and fructosebisphosphate aldolase could not be detected in cell extracts of Pseudomonas $\mathrm{C}$ (results not shown) indicating that glucose is not metabolized through glycolysis; $(b)$ no activity of 2-oxoglutarate dehydrogenase could be detected in cell extracts of Pseudomonas C (Ben-Bassat \& Goldberg, 1977) indicating that glucose is not oxidized through the tricarboxylic acid cycle; $(c)$ the ratio of ${ }^{14} \mathrm{CO}_{2}$ originating from $\left[1-{ }^{14} \mathrm{C}\right]$ glucose 6 -phosphate to that originating from $\left[\mathrm{U}-{ }^{14} \mathrm{C}\right]$ glucose 6 -phosphate in cell extracts of this bacterium was found to be close to 6 (Ben-Bassat \& Goldberg, 1977), indicating that glucose is oxidized to $\mathrm{CO}_{2}$ primarily via the oxidative glucose monophosphate shunt, i.e. via glucose-6-phosphate dehydrogenase and 6-phosphogluconate dehydrogenase; $(d)$ the activity of the KDPG aldolase reaction was relatively high in cell extracts of Pseudomonas C (results not shown); (e) the incorporation of $\left[\mathrm{U}-{ }^{14} \mathrm{C}\right] \mathrm{glucose}$ into cells was very high $(78 \%$; see Table 1$)$; and $(f)$ the amount of glucose consumed by the cells $\left(50 \mathrm{mg} \mathrm{l}^{-1}\right)$ comprised only $1 \cdot 25 \%$ of the amount of methanol $\left(4 \mathrm{~g}^{-1}\right)$ which was simultaneously consumed, and is therefore unlikely to cause any change in patterns of metabolism as far as these pathways are concerned.

(iii) Formic acid is incorporated into cells neither directly nor via reduction to formaldehyde and is oxidized to $\mathrm{CO}_{2}$. This assumption is supported by the following findings: (a) under the experimental conditions used, no production of formaldehyde from exogenous formate was detected in Pseudomonas C; $(b)$ the activities of the different enzymes of the serine pathway (Ribbons et al., 1970), required for the assimilation of formate, could not be detected in this organism (Stieglitz \& Mateles, 1972; Ben-Bassat \& Goldberg, 1977); (c) formic acid and bicarbonate were incorporated into methanol-grown cells to a similar extent (Table 1); and $(d)$ aeration of the chemostat with $\mathrm{CO}_{2}$-enriched air reduced the incorporation of $\left[{ }^{14} \mathrm{C}\right]$ formate into cells (Table 1 ).

(iv) Evidence for net incorporation of $\mathrm{CO}_{2}$ in methanol-grown Pseudomonas $\mathrm{C}$ is supported by the following: (a) Battat et al. (1974) showed that $\mathrm{CO}_{2}$ is necessary for obtaining high yields of this bacterium; $(b)$ in methanol-grown Pseudomonas W6, a bacterium similar in many respects to Pseudomonas C (Miethe \& Babel, 1976), Babel \& Loffhagen (1977) reported the presence of high activities of phosphoenolpyruvate carboxylase and pyruvate carboxylase, and they suggested that a high rate of carboxylation is necessary for synthesis of $\mathrm{C}_{4}$ dicarboxylic acids in methylotrophic bacteria which use the RMP pathway for the assimilation of $\mathrm{C}_{1}$ compounds and which possess an incomplete tricarboxylic acid cycle that serves only for biosynthetic purposes; $(c)$ the possibility that the incorporation of ${ }^{14} \mathrm{CO}_{2}$ is primarily due to exchange reactions (Quayle, 1961) seems unlikely since these methylotrophic bacteria when grown on methanol must synthesize $\mathrm{C}_{4}$ dicarboxylic acids by carboxylation of $\mathrm{C}_{3}$ acids.

Since there is still a possibility that a small amount of the ${ }^{14} \mathrm{CO}_{2}$ was incorporated into 
cells via $\mathrm{CO}_{2}$ exchange reactions (Quayle, 1961), we have calculated fluxes of methanol carbon for the extreme possibility that no net $\mathrm{CO}_{2}$ incorporation occurs (Table 4). The changes observed in the fluxes of methanol carbon were in the range of 4 to $25 \%$ (Tables 2 and 4) and since it is expected that only a small amount of ${ }^{14} \mathrm{CO}_{2}$ is incorporated into cells through exchange reactions, the actual values of the fluxes of methanol carbon in methanolgrown Pseudomonas $\mathrm{C}$ must be close to the results calculated and presented in Table 2.

When Pseudomonas $\mathrm{C}$ was grown on methanol as sole carbon source, $45 \%$ of the methanol carbon consumed by the cells was oxidized to $\mathrm{CO}_{2}$ by the following pathways: $25 \%$ via formic acid, producing NADH for energy requirements, and $20 \%$ via the cyclic oxidation pathway and assimilatory decarboxylation reactions [for example, the isocitrate dehydrogenase reaction discussed by Babel \& Loffhagen (1977)] producing NADH and NADPH for energy and biosynthetic purposes (Ben-Bassat \& Goldberg, 1977) (Fig. 1 and Table 2). Assimilation of methanol in Pseudomonas $\mathrm{C}$ occurred via the KDPG variant of the RMP assimilation pathway (55\% of the total carbon) and via carboxylation reactions $(7 \%)$ (Table 2). The re-incorporation of $\mathrm{CO}_{2}$ into cell material might be effected through carboxylation of phosphoenolpyruvate and pyruvate as was suggested by Babel \& Loffhagen (1977). Since almost all the RMP methylotrophic bacteria have an incomplete tricarboxylic acid cycle which serves only for biosynthetic purposes (Colby \& Zatman, 1975), such a degree of net $\mathrm{CO}_{2}$ incorporation would be expected (Quayle, 1961; Wiame \& Bourgeois, 1955). This must be taken into consideration in labelling experiments and in calculating theoretical growth yields (van Dijken \& Harder, 1975; Anthony, 1977).

Supplementation of the medium with formic acid provided a means of supplying unlimited energy while limiting the carbon available for biosynthesis. The resulting increase in yield calculated on the basis of methanol (Fig. 3) arises from a diversion of more equivalents of methanol into the RMP assimilatory pathway and from an increase in the amount of $\mathrm{CO}_{2}$ assimilated. These two processes were presumably being facilitated by the energy provided from the oxidation of exogenous formic acid to $\mathrm{CO}_{2}$. The highest yield obtained at a molar ratio of formic acid to methanol of 0.4 possibly resulted from the fact that the cyclic oxidation pathway and the assimilatory decarboxylation reactions produce NADPH required for biosynthesis, as well as NADH and NADPH for energy purposes (Ben-Bassat \& Goldberg, 1977; Babel \& Loffhagen, 1977), and thus must operate even though there is available excess of formic acid, the oxidation of which produces only NADH (Ben-Bassat \& Goldberg, 1977). The question of whether the direct oxidation pathway is necessary for the growth of this bacterium remains open and is under examination via attempts to isolate mutants lacking formate dehydrogenase.

When the in vivo activities of different enzymes are compared for growth on methanol and on methanol plus formic acid (Table 5), there is a substantial increase in formate dehydrogenase activity and a substantial decrease in formaldehyde dehydrogenase activity. The first is accounted for by the oxidation of exogenous formic acid, while the second represents a shift of more methanol equivalents into the RMP pathway. A comparison of in vitro activities, i.e. an estimate of the amount of enzyme present, shows identical activities for the two growth conditions. Thus, it is likely that the control of carbon flow is exercised not by varying the rates of synthesis of the various enzymes (which is reflected in their steady state concentrations), but rather through effects on the activities of these enzymes.

The lack of agreement between in vivo and in vitro measurements of these enzymes is not surprising since in vitro assays did not simulate the cell's internal environment. For methanol dehydrogenase there is no reason to expect identical in vivo and in vitro activities since the electron acceptor used in vitro is definitely not the natural one, which is unknown (Ribbons et al., 1970). For formaldehyde dehydrogenase the picture is complicated by the presence of several activities only one of which (the $\mathrm{NAD}^{+}$-dependent one) is reported here. An activity dependent on 2,6-dichlorophenolindophenol has been reported in Pseudomonas C (Ben-Bassat \& Goldberg, 1977), while in some bacteria a total of three activities of 
formaldehyde dehydrogenase can be detected (Quayle, 1972). Thus additional enzyme activities might explain the discrepancy.

This research is part of a doctoral dissertation to be submitted by A. Ben-Bassat to the Hebrew University of Jerusalem. The research was supported by a grant from the U.S.Israel Binational Science Foundation.

\section{REFERENCES}

Anthony, C. (1977). The prediction of growth yields in methylotrophs. Journal of General Microbiology 104, 91-104.

Babel, W. \& Loffhagen, N. (1977). Carboxylierung von Phosphoenolpyruvate und Pyruvate durch das obligat methylotrophe Bakterium Pseudomonas W6. Zeitschrift für allgemeine Mikrobiologie 17, 75-79.

Battat, E., GoldberG, I. \& Mateles, R. I. (1974). Growth of Pseudomonas $\mathrm{C}$ on $\mathrm{C}_{1}$ compounds: continuous culture. Applied Microbiology 28, 906911.

Ben-Bassat, A. \& Goldberg, I. (1977). Oxidation of $\mathrm{C}_{1}$-compounds in Pseudomonas $\mathrm{C}$. Biochimica et biophysica acta 497, 586-597.

BRAY, G. A. (1960). A simple efficient liquid scintillator for counting aqueous solutions in a liquid scintillation counter. Analytical Biochemistry 1, 279-285.

Chalfan, Y. \& Mateles, R. I. (1972). New pseudomonad utilizing methanol for growth. Applied Microbiology 23, 135-140.

Colby, J. \& ZATMAn, L. J. (1975). Tricarboxylic acid-cycle and related enzymes in restricted facultative methylotrophs. Biochemical Journal 148, 505-511.

van Dijken, J. P. \& Harder, W. (1975). Growth yields of microorganisms on methanol and methane. A theoretical study. Biotechnology and Bioengineering 17, 15-30.

Goldberg, I., Rock, J. S., Ben-Bassat, A. \& MAteles, R. I. (1976). Bacterial yields on methanol, methylamine, formaldehyde and formate. Biotechnology and Bioengineering 18, 1657-1668.

Ling, K. H., PaetKau, V., Markus, F. \& Lardy, H. A. (1966). Phosphofructokinase I. Skeletal muscle. Methods in Enzymology 9, 425-429.

Mateles, R. I. \& Battat, E. (1974). Continuous culture used for media optimization. Applied Microbiology 28, 901-905.

Miethe, D. \& BABEL, N. (1976). Regulation der Glucose-6-phosphate Dehydrogenase aus dem obligat methylotrophen Bakterium Pseudomonas W6. Zeitschrift für allgemeine Mikrobiologie 16, 289-299.

QUAYLE, J. R. (1961). Metabolism of $C_{1}$ compounds in autotrophic and heterotrophic microorganisms. Annual Review of Microbiology 15, 119-152.

QuAYLE, J. R. (1972). The metabolism of $\mathrm{C}_{1}$ compounds by microorganisms. Advances in Microbial Physiology 7, 119-203.

Ribbons, D. W., Harrison, J. E. \& WadzinsKy, A. M. (1970). Metabolism of single carbon compounds. Annual Review of Microbiology 24, 135-158.

Stieglitz, B. \& Mateles, R. I. (1973). Methanol metabolism in Pseudomonas C. Journal of Bacteriology 114, 390-398.

Strøm, T., Ferenci, T. \& Quayle, J. R. (1974). The carbon assimilation pathways of Methylococcus capsulatus, Pseudomonas methanica and Methylosinus trichosporium (OB3B) during growth on methane. Biochemical Journal 144, 465-476.

TAYLOR, I. J. (1977). Carbon assimilation and oxidation by Methylophilus methylotrophus - the ICI SCP organism. In Microbial Growth on $C_{1}$ Compounds: Abstracts of the International Symposium, pp. 52-54. Pushchino: USSR Academy of Science.

TAYLOR, R. T. \& WEISSBACH, H. (1965). Radioactive assay for serine transhydroxymethylase. Analytical Biochemistry 13, 80-84.

Wiame, J. M. \& Bourgeois, S. (1955). Le role de l'anhydride carbonique dans les croissances bacteriennes. Biochimica et biophysica acta 18, 269-278. 